\title{
FILIP TERESZKIEWICZ
}

Politechnika Opolska

ORCiD: 0000-0001-8551-0250

\section{Analiza dokumentów strategicznych Unii Europejskiej: Human Security jako paradygmat unijnej polityki przeciwdziałania terroryzmowi}

W powszechnym odczuciu terroryzm od wielu już lat postrzegany jest jako jedno z głównych zagrożeń bezpieczeństwa Europy. Jest to jeden z niewielu tematów, na które toczy się paneuropejska debata angażująca zarówno polityków i ekspertów, jak i zwykłych obywateli. Społeczeństwa wielu państw członkowskich Unii Europejskiej mają, mniej lub bardziej uzasadnione, poczucie zagrożenia ze strony terrorystów ${ }^{1}$. Wydaje się więc, iż wyzwanie to stało się idealnym obszarem zacieśniania współpracy w ramach zjednoczonej Europy. Na przeszkodzie temu stoi jednak umieszczenie polityki bezpieczeństwa wewnętrznego w sferze wyłącznych kompetencji państw członkowskich. Tak więc z jednej strony istnieje w Unii świadomość konieczności intensyfikacji współpracy w kwestii zwalczania terroryzmu z racji ogólnoeuropejskiego charakteru tego wyzwania, z drugiej zaś można zauważyć niechęć (uzasadnioną regulacjami traktatowymi) rządów państw członkowskich do przekazywania kompetencji w omawianej sferze na poziom unijny ${ }^{2}$. Adekwatnym rozwiązaniem tej sytuacji stało się zacieśnienie współpracy w zwalczaniu terroryzmu za pomocą nie tyle aktów prawnych, ile wyznaczających pewne cele i zasady dokumentów strategicznych. Są one jednak przygotowywane na poziomie unijnym, co sprawia, iż dominuje w nich pewien

${ }^{1}$ Zob. Europejczycy w 2016 roku: Wyobrazenia i oczekiwania, walka z terroryzmem i radykalizacja postaw. Wydanie specjalne Eurobarometru Parlamentu Europejskiego, 2016, PE 570423, http://www.europarl.europa.eu/pdf/eurobarometre/2016/attentes/eb85_1_synthesis_perceptions_ wishes_terrorism_pl.pdf (dostęp: 4.05.2017).

${ }^{2}$ Zob. S. Wojciechowski, Polityka antyterrorystyczna Unii Europejskiej-syndrom , różnych prędkości” i próby jego ograniczenia, „Biuletyn Instytutu Zachodniego” 2017, nr 298. 
charakterystyczny sposób myślenia typowy dla instytucji ponadnarodowych. Celem niniejszej pracy jest analiza obowiązujących dokumentów strategicznych Unii Europejskiej, odnoszących się do polityki przeciwdziałania terroryzmowi pod kątem obecności w nich typowego dla unijnej polityki bezpieczeństwa paradygmatu Human Security.

\section{Human Security jako paradygmat polityki bezpieczeństwa Unii Europejskiej}

W literaturze panuje konsensus, iż polityka bezpieczeństwa Unii Europejskiej, niezależnie od tego, czy dotyczy bezpieczeństwa wewnętrznego, czy zewnętrznego, oparta jest na paradygmacie Human Security (inaczej bezpieczeństwo ludzkie, bezpieczeństwo jednostki ludzkiej) ${ }^{3}$. Potwierdza to analiza unijnych dokumentów strategicznych, zarówno nieobowiązujących już europejskiej strategii bezpieczeństwa z 2003 roku $^{4}$ oraz strategii bezpieczeństwa wewnętrznego z $2010 \mathrm{roku}^{5}$, jak i aktualnych dokumentów, tj. europejskiej agendy bezpieczeństwa z 2015 roku $^{6}$ oraz globalnej strategii Unii Europejskiej z 2016 roku$^{7}$. Wszystkie one noszą cechy typowe dla wspomnianego paradygmatu, a więc opierają się na założeniu, iż polityka bezpieczeństwa powinna koncentrować się przede wszystkim na zapewnieniu poczucia bezpieczeństwa jednostce ludzkiej ${ }^{8}$.

Paradygmat Human Security został stworzony w opozycji do pojęcia bezpieczeństwa narodowego. Powstał on w kontekście upadku Związku Radzieckiego i zakończenia Zimnej Wojny. Uznano wtedy, iż tradycyjne wyzwania dla bezpie-

3 S. Fukuda-Parr, C. Messineo, Human Security: a critical review of the literature, „CRPD Working Paper" 2012, nr 11, s. 10-11; D. Trachsler, Human Security: Genesis, Debates, Trends, „CSS Analysis in Security Policy” 2011, nr 90, s. 3.

4 Europejska strategia bezpieczeństwa „,Bezpieczna Europa w lepszym świecie”, http://www. consilium.europa.eu/media/30814/qc7809568plc.pdf (dostęp: 2.05.2017).

5 Strategia bezpieczeństwa wewnętrznego Unii Europejskiej „,Dążac do europejskiego modelu bezpieczeństwa", 2010, https://europa.eu/globalstrategy/en/file/10/download?token=ubYn8qBQ (dostęp: 2.05.2017).

${ }^{6}$ Komunikat Komisji do Parlamentu Europejskiego, Rady, Europejskiego Komitetu Ekonomiczno-Społecznego i Komitetu Regionów, Europejska agenda bezpieczeństwa, Strasburg, 28.04.2015, $\operatorname{COM}(2015) 185$ final.

7 Globalna strategia na rzecz polityki zagranicznej i bezpieczeństwa Unii Europejskiej „Wspólna wizja, wspólne działanie: Silniejsza Europa”, http://eeas.europa.eu/archives/docs/top_ stories/pdf/eugs_pl_.pdf(dostęp: 4.05.2017).

8 Jest to efekt oparcia pierwszych dokumentów strategicznych UE na pracy tzw. grupy barcelońskiej powołanej przez wysokiego przedstawiciela ds. WPZiB. Grupa ta zaproponowała Human Security jako paradygmat polityki bezpieczeństwa UE. Zob. Study Group on Europe's Security Capabilities, A human security doctrine for Europe: the Barcelona report, 2004, s. 9-10, http://www.lse.ac.uk/internationalDevelopment/research/CSHS/humanSecurity/barcelonaReport. pdf (dostęp: 6.05.2017). 
czeństwa, takie m.in. jak konflikt zbrojny, konflikt nuklearny, podważanie systemu konstytucyjnego czy klasyczne ataki na terytorium i infrastrukturę państwa, są przeszłością ${ }^{9}$. Najdobitniej wyrażone to zostało przez F. Fukuyamę w jego słynnej publikacji Koniec historii ${ }^{10}$. $\mathrm{O}$ ile niewielu specjalistów zgadzało się $\mathrm{z}$ amerykańskim politologiem, iż wraz z upadkiem Związku Radzieckiego zaniknie wojna, to jednak powszechne było przekonanie, że doszło w tym czasie do tryumfu liberalnej demokracji i kapitalistycznego modelu gospodarczego. Opierając się na założeniu, że demokracje nie toczą z sobą wojen, uznano, iż podstawowym wyzwaniem w najbliższych latach stanie się walka z globalnymi nierównościami, jako głównym źródłem destabilizacji ${ }^{11}$.

Analizowane podejście do polityki bezpieczeństwa zostało spopularyzowane w latach 90. XX wieku przez Program Narodów Zjednoczonych na rzecz rozwoju. W swoim Raporcie o Rozwoju Społecznym z 1994 roku podkreślił on, że najlepszą drogą do rozwiązania problemu globalnego zagrożenia jest wzbudzenie w każdym człowieku poczucia wolności od niedostatku i wolności od strachu ${ }^{12}$. Tym samym polityka bezpieczeństwa według tej agendy ONZ powinna koncentrować się przede wszystkim na ochronie ludzi poprzez promowanie pokoju, zapewnienie zrównoważonego rozwoju oraz przeciwdziałanie nierównościom, które oddziałują na bezpieczeństwo ${ }^{13}$.

Pomimo upływu ponad trzech dekad pojęcie Human Security nadal jednak nie doczekało się jasnego sprecyzowania, co jest podstawowym źródłem kryty$\mathrm{ki}^{14}$. Niemniej można wskazać kilka definiujących je cech. Przede wszystkim polityka bezpieczeństwa według omawianego paradygmatu powinna być skoncentrowana na ludziach/jednostkach, w przeciwieństwie do tradycyjnie pojmowanego bezpieczeństwa, które jest skoncentrowane na państwie ${ }^{15}$. Głównym obszarem zainteresowania polityki bezpieczeństwa powinno być więc zaspokojenie podstawowych potrzeb ludzi, niedostatek bowiem jest podstawowym źródłem braku poczucia bezpieczeństwa. Ponadto, celem polityki bezpieczeństwa musi być ochrona nie tylko przed agresją zewnętrzną, ale również — a może przede wszystkim — przed dużo szerzej rozumianymi zagrożeniami, w tym m.in. zanieczyszczeniem środowiska naturalnego, chorobami zakaźnymi, bezrobociem czy

${ }^{9}$ M. Kaldor, Human Security: Reflections on Globalization and Intervention, Cambridge 2007, s. 10; M. ul Haq, Reflections on Human Development, New York 1995, s. 115; D. Trachsler, op. cit., s. 1 .

10 F. Fukuyama, Koniec historii, tłum. T. Bieroń, M. Wichrowski, Kraków 2009.

11 D. Trachsler, op. cit., s. 1-2.

12 Human Development Report 1994, New York-Oxford 1994, s. 22-40.

13 Szerzej na ten temat w: R. Tarnogórski, Human Security: Reactivation of an Idea?, „PISM Strategic File" 2013, nr 2, s. 1-2.

14 Zob. R. Paris, Human Security. Paradigm Shift or Hot Air?, „International Security” 2001, vol. 26, nr 2; S. Fukuda-Parr, C. Messineo, op. cit., s. 12-13.

15 K. Bajpai, The idea of Human Security, „International Studies” 40, nr 3, 2003, s. 195-228; S. Fukuda-Parr, C. Messineo, op. cit., s. 2-3. 
ogólnie obniżeniem jakości życia ${ }^{16}$. Dodatkowo, w myśl tego podejścia, aktorami zaangażowanymi $\mathrm{w}$ działania $\mathrm{w}$ obszarze polityki bezpieczeństwa powinny być nie tylko państwa/rządy państw, lecze także niepaństwowi aktorzy, tacy jak regionalne i międzynarodowe organizacje, społeczeństwo obywatelskie, lokalne i regionalne społeczności czy przedsiębiorstwa prywatne ${ }^{17}$.

\section{Polityka antyterrorystyczna w dokumentach strategicznych Unii Europejskiej}

W początkowej fazie integracji europejskiej zagrożenie terrorystyczne nie było traktowane jako niezbędny obszar współpracy między państwami członkowskimi. Związane to było z faktem, iż od samego początku politycy europejscy uznawali, że problematyka bezpieczeństwa wewnętrznego powinna zostać wyłączną domeną państw członkowskich. Sytuacja ta uległa zmianie w latach 70 . $\mathrm{XX}$ wieku, kiedy to w krajach Europy Zachodniej nasiliły się ataki terrorystycz$n \mathrm{e}^{18}$. Szybko okazało się, iż ugrupowania przeprowadzające zamachy wykorzystują brak współdziałania pomiędzy służbami państw członkowskich i ukrywają się w sąsiednich krajach. Skłoniło to liderów ówczesnej Europejskiej Wspólnoty Gospodarczej do podjęcia rozmów na temat stworzenia mechanizmów umożliwiających współpracę zainteresowanych służb przy zwalczaniu terroryzmu ${ }^{19}$.

Integracja $\mathrm{w}$ tej kwestii wraz $\mathrm{z}$ upływem lat $\mathrm{w}$ zasadzie nie posuwała się do przodu, pozostawiając kompetencje w wyłącznej domenie poszczególnych państw, przy czym rola struktur ponadnarodowych ograniczała się jedynie do tworzenia mechanizmów zapewniających efektywną współpracę agencji rządowych ${ }^{20}$. Momentem przełomowym było wejście w życie traktatu z Maastricht, który utworzył Unię Europejską opartą na trzech filarach. Jednym z nich była współpraca w obszarze spraw wewnętrznych i wymiaru sprawiedliwości, która stanowiła płaszczyznę współdziałania również kwestii zwalczania terroryzmu ${ }^{21}$.

${ }^{16}$ E. Rothschild, What is Security, „Daedalus” 124, 1995, nr 3, s. 55; S. Fukuda-Parr, C. Messineo, op. cit., s. 4.

17 R. Tarnogórski, op. cit., s. 2-3. Takie przekonanie wynika głównie z faktu, iż często głównym zagrożeniem dla bezpieczeństwa jednostek są rządy państw, w których żyją. D. Trachsler, op. cit., s. 2.

18 C. Beyer, The European Union as a Security Policy Actor: The Case of Counterterrorism, „European Foreign Affairs Review” 13, 2008, nr 3, s. 306.

19 Rozmowy te toczyły się w ramach grup TREVI. Zob. I. Resztak, Zwalczanie terroryzmu w świetle dokumentów Unii Europejskiej, „Prokuratura i Prawo” 2013, nr 5, s. 132; J. Gierszewski, Unia Europejska w walce z terroryzmem międzynarodowym, „Acta Pomerania” 2009, nr 2, s. 137-138.

20 P. Durys, F. Jasiński, Zwalczanie terroryzmu w ramach Unii Europejskiej, „Wspólnoty Europejskie" 2000, nr 6 (106), s. 53.

${ }^{21}$ M. Den Boer, 9/11 and the Europeanisation of Anti-Terrorism Policy: A Critical Assessment, „Policy Papers” 2003, nr 6, s. 1; D. Szacher, Walka z terroryzmem w Unii Europejskiej nowy impuls, Torun 2006, s. 101. 
Decydujące znaczenie dla zacieśnienia współpracy w analizowanym temacie miały jednak zamachy terrorystyczne z 11 września $2001 \mathrm{roku}^{22}$. Uświadomiły one przywódcom państw członkowskich, że terroryzm będzie jednym z głównych wyzwań początku XXI wieku ${ }^{23}$. Z tego też powodu w 2002 roku została przyjęta przez Radę decyzja ramowa 2002/475/WSiSW ${ }^{24}$, która była pierwszym ogólnounijnym dokumentem regulującym całościowo kwestię walki z terroryzmem. W następnym roku została zaakceptowana europejska strategia bezpieczeństwa dotycząca zewnętrznego wymiaru tej polityki. Wskazała ona terroryzm jako jedno z czołowych wyzwań stojących przed Unią Europejską i jej państwami członkowskimi ${ }^{25}$. Dwa lata później, to jest w 2005 roku, Komisja Europejska zaprezentowała kolejny dokument strategiczny dotyczący już stricte przeciwdziałania terroryzmowi ${ }^{26}$. Pomimo upływu ponad dekady strategia ta zachowała swoją aktualność, co świadczy o tym, iż była ona dobrze przygotowana, czego nie można powiedzieć o wszystkich dokumentach strategicznych UE ${ }^{27}$.

W połowie drugiej dekady XXI wieku liderzy Unii Europejskiej doszli jednak do przekonania, iż konieczne jest przyjęcie nowych dokumentów strategicznych dotyczących polityki bezpieczeństwa. W 2015 roku przez Komisję zaprezentowana została europejska agenda bezpieczeństwa dotycząca wymiaru wewnętrznego tej polityki, pod koniec czerwca 2016 roku zaś Federica Mogherini (wysoka przedstawiciel do spraw zagranicznych i polityki bezpieczeństwa) przedstawiła Radzie Europejskiej globalną strategię UE odnoszącą się do wymiaru zewnętrznego.

Obydwa obowiązujące unijne dokumenty strategiczne traktują terroryzm jako jedno z głównych zagrożeń bezpieczeństwa Unii, jej państw członkowskich oraz ich obywateli. Europejska agenda bezpieczeństwa umieszcza go wśród trzech najważniejszych wyzwań bezpieczeństwa wewnętrznego UE (pozostałe to cyberprzestępczość i przestępczość zorganizowana) ${ }^{28}$. Z kolei w globalnej strategii UE terroryzm znajduje się $\mathrm{w}$ jednym z pięciu wskazanych tam priorytetów, tj. w „Bezpieczeństwie naszej Unii”. Oprócz niego wskazuje się w nim jako

${ }^{22}$ Wydarzenie to miało również wpływ na spadek popularności podejścia Human Security. D. Trachsler, op. cit., s. 2.

23 A. Gruszczak, Governing Internal Security in the European Union, „CEJISS” 2, 2010, nr 3, s. 94-95.

24 Decyzja ramowa Rady z dnia 13 czerwca 2002 r. w sprawie zwalczania terroryzmu (2002/475/WSiSW), Dz. Urz. UE z 2002 r. L 164/3.

25 Europejska strategia bezpieczeństwa..., s. 3. Zob. M. Sus, Member States as StrategyMaker or Strategy-Taker?, „Polish Political Science Yearbook” 2016, nr 45, s. 338.

26 Strategia UE $w$ dziedzinie walki z terroryzmem, Bruksela 30.11.2005, 14469/4/05, http:// register.consilium.europa.eu/doc/srv? $\mathrm{f}=\mathrm{ST}+14469+2005+\mathrm{REV}+4 \& \mathrm{l}=\mathrm{pl}$ (dostęp: 4.05.2017).

27 Główny zarzut wobec większości dokumentów strategicznych UE można sprowadzić do tego, że ze względu na zakorzenienie w bieżącej sytuacji nie mają one charakteru strategicznego. Zob. F. Tereszkiewicz, Europejska strategia bezpieczeństwa wobec współczesnych wyzwań bezpieczeństwa Unii Europejskiej, [w:] Współczesna polityka bezpieczeństwa. Aspekty polityczne, gospodarcze i militarne, red. P. Grata, M. Deląg, P. Korzeniowski, Rzeszów 2016, s. 17-18.

${ }^{28}$ Komunikat Komisji do Parlamentu..., s. 14. 
główne wyzwania dla bezpieczeństwa obywateli Unii zagrożenia hybrydowe, niestabilność gospodarczą, zmiany klimatu i brak bezpieczeństwa energetyczne$\mathrm{go}^{29}$. Ponadto $\mathrm{w}$ ramach tego priorytetu jednym z głównych kierunków działania $\mathrm{w}$ obszarze bezpieczeństwa ma być zwalczanie terroryzmu ${ }^{30}$. Warte podkreślenia jest jednak to, że również w pozostałych priorytetach akcentuje się konieczność podjęcia działań zmierzających do przeciwdziałania terroryzmowi (np. w ramach priorytetu „Łady regionalne oparte na wspólpracy” proponuje się zacieśnienie współpracy z Radą Państw Zatoki Perskiej, Unią Afrykańską czy ASEAN ${ }^{31}$ ).

Analizując obydwa dokumenty z punktu widzenia polityki zwalczania terroryzmu, można zauważyć pewne punkty wspólne. Przede wszystkim zagrożenie terrorystyczne jest obszarem wymagającym holistycznego podejścia, tzn. łączenia $\mathrm{z}$ sobą działań $\mathrm{w}$ sferze polityki bezpieczeństwa wewnętrznego i zewnętrznego. Wskazuje się w nich wyraźnie, iż natura tego zagrożenia jest tak złożona i kompleksowa, że nie jest możliwe przeciwdziałanie mu bez zaangażowania całego spektrum polityk i instrumentów, którymi dysponuje Unia i jej państwa członkowskie. $Z$ tego też powodu drugą rzeczą, jaką obydwa dokumenty proponują w sprawie zwalczania terroryzmu, jest ustanowienie ściślejszej współpracy pomiędzy państwami członkowskimi (współpraca horyzontalna) oraz pomiędzy państwami członkowskimi a Unią (współpraca wertykalna). Podkreśla się w nich bardzo wyraźnie wartość dodaną zaangażowania wspólnoty, oczywiście w oparciu o zasadę pomocniczości. Trzecią propozycją zawartą w obu dokumentach jest intensyfikacja współpracy $\mathrm{w}$ przeciwdziałaniu terroryzmowi z partnerami zewnętrznymi i aktorami niepaństwowymi. Wskazuje się, że granice nie są przeszkodą dla terrorystów, dlatego też konieczne jest podjęcie ściślejszej współpracy z krajami pochodzenia terrorystów, a także działającymi w nich aktorami niepaństwowymi (społecznością lokalną, miejscowymi autorytetami, organizacjami pozarządowymi). Ostatnią narracją wspólną dla obydwu dokumentów jest przekonanie, że najskuteczniejszym instrumentem walki z terroryzmem jest prewencja. Przeciwdziałanie radykalizacji postaw, walka z ekstremistyczną propagandą czy wzmocnienie państw w sąsiedztwie Unii przyniesie dużo lepsze efekty dla wspólnoty niż przygotowywanie się jedynie na ewentualność wystąpienia ataku terrorystycznego.

29 Globalna strategia na rzecz polityki..., s. 17.

30 S. Koziej, Strategia globalna UE: szanse i dalsze wyzwania wdrożeniowe, „Pułaski Policy Papers" 2017, s. 5.

31 Ibidem, s. 33-34. 


\section{Czy unijna polityka przeciwdziałania terroryzmowi wpisuje się w paradygmat Human Security?}

Tak jak to zostało wspomniane, celem niniejszej pracy jest odpowiedź na pytanie, czy unijna polityka przeciwdziałania terroryzmowi oparta jest na paradygmacie bezpieczeństwa ludzkiego ${ }^{32}$. Pomimo iż w deklaracji barcelońskiej wskazano Human Security jako najlepszą strategię w walce z terroryzmem ${ }^{33}$, to jednak nie musiało się to przełożyć na najnowsze dokumenty strategiczne. Aby odpowiedzieć na postawione pytanie, trzeba w omawianej polityce zidentyfikować cechy typowe dla tytułowego podejścia. Na potrzeby niniejszej pracy zdefiniowane zostały trzy wskaźniki, które sprowadzają się do następujących pytań: 1) Czy jednostka ludzka (ludzie) traktowana jest jako główny podmiot ochrony? 2) Czy zagrożenia są definiowane szeroko i wykraczają poza sam akt terroru? 3) Czy przewiduje się zaangażowanie aktorów niepaństwowych? Jeżeli w przypadku wszystkich analizowanych dokumentów trzy odpowiedzi będą pozytywne, to zostanie wykazane, że są one oparte na paradygmacie Human Security. W przypadku nawet jednej negatywnej odpowiedzi okaże się, że analizowana polityka nie jest oparta na tytułowym podejściu.

W celu zbadania założeń unijnej polityki przeciwdziałania terroryzmowi przeanalizowane zostały obowiązujące unijne dokumenty dotyczące tej sfery aktywności. Skupiono się więc na trzech dokumentach strategicznych, tj. unijnej strategii w dziedzinie walki z terroryzmem, europejskiej agendzie bezpieczeństwa oraz globalnej strategii UE.

\subsection{Czy jednostka ludzka jest traktowana jako główny podmiot ochrony polityki przeciwdziałania terroryzmowi?}

Unijna strategia w dziedzinie walki z terroryzmem bardzo wyraźnie wskazuje, że ochrona obywateli (ale też infrastruktury) jest jej podstawowym celem ${ }^{34}$. Strategia ta poświęca też uwagę kwestii odpowiedniej pomocy ofiarom ataków terrorystycznych ${ }^{35}$, co pośrednio potwierdza, że jest ona skupiona na zapewnieniu poczucia bezpieczeństwa ludziom ${ }^{36}$.

W przypadku europejskiej agendy bezpieczeństwa również można powiedzieć, iż jej celem jest ochrona jednostki ludzkiej. Wyraźnie ona mówi, że „obywa-

32 A. Zwitter przeprowadził takie badanie w stosunku do polityki przeciwdziałania terroryzmowi, nie koncentrując się jednak na podejściu Unii to tego zagadnienia. Zob. A. Zwitter, Human Security, Law and the Prevention of Terrorism, London-New York 2011.

33 Study Group on Europe's Security Capabilities, op. cit., s. 10.

34 Strategia UE..., s. 3.

35 Ibidem, s. 17.

36 C. Beyer, op. cit., s. 302. 
tele $[\ldots]$ oczekują wsparcia UE w walce $\mathrm{z}$ terroryzmem i radykalizacją postaw oraz ułatwianiu koordynacji i współpracy między właściwymi organami” ${ }^{37}$. Tym samym podkreśla się $\mathrm{w}$ tym dokumencie, że nadanie określonych kompetencji wspólnocie w obszarze polityki zwalczania terroryzmu wynika z oczekiwań społecznych. Obywatele Unii pokładają w niej nadzieje, licząc, iż pomoże ona zapewnić odpowiednią współpracę między organami i służbami państw członkowskich. Świadczy to więc o tym, że pośrednio jej celem jest zapewnienie poczucia bezpieczeństwa wśród ludzi.

W przypadku globalnej strategii UE również mamy do czynienia ze spełnieniem tego warunku, już na jej samym początku bowiem wskazuje się, że bezpieczeństwo obywateli Unii jest jej priorytetem ${ }^{38}$. Odnosi się to do wszystkich opisanych w niej polityk, w tym również tej dotyczącej zwalczania terroryzmu. Ponadto wyraźnie w tym dokumencie podkreśla się, iż Unia ma „interes w [...] promowaniu bezpieczeństwa ludzkiego" ${ }^{39}$, co jest literalnym odniesieniem się do paradygmatu Human Security.

\subsection{Czy zagrożenia związane z terroryzmem są definiowane szeroko?}

Unijna strategia w dziedzinie walki z terroryzmem wskazuje, że zagrożeniem są nie tylko same akty terroru, lecz również wszystko to, co prowadzi do terroryzmu i co po nim następuje ${ }^{40}$. W tym kontekście wymienia radykalizację postaw, rekrutację kandydatów na terrorystów, ekstremistyczną propagandę, a także konsekwencje dla ofiar zamachów terrorystycznych pochodzących z innych państw członkowskich ${ }^{41}$. Wskazuje ona również, że podstawowym problemem są niesprawne lub autorytarne rządy w najbliższym otoczeniu Unii, które prowadzą do radykalizacji postaw mieszkańców tych państw ${ }^{42}$.

$\mathrm{Z}$ kolei europejska agenda bezpieczeństwa również na pierwszym miejscu wymienia akty terroru ${ }^{43}$, ale jej myślą przewodnią jest wspomniana wcześniej teza, że terroryzm jest obecnie powiązany z cyberprzestępczością i przestępczością zorganizowaną ${ }^{44}$. To zaś sprawia, iż za zagrożenia o charakterze terrorystycznym należy uznać również działania $\mathrm{w}$ tych dwóch obszarach, jeżeli są one bezpośrednio lub pośrednio powiązane $\mathrm{z}$ terroryzmem. Agenda wymienia również powracających zagranicznych bojowników, ekstremistyczne ideologie

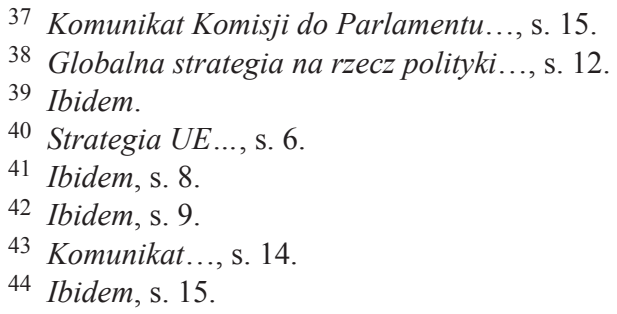


i propagandę jako czynniki mogące stanowić zagrożenie bezpieczeństwa obywateli Uniii ${ }^{45}$.

Globalna strategia UE w kwestii polityki zwalczania terroryzmu również wskazuje akt terroru jako czynnik zagrażający bezpieczeństwu unijnych obywateli ${ }^{46}$. W tym kontekście wymienia także wpływ braku odporności na rozwój tego zagrożenia państw w najbliższym sąsiedztwie UE ${ }^{47}$. Wyszczególnia ponadto brak zintegrowanego podejścia do sytuacji kryzysowych i zbyt wczesne wycofywanie się jako elementy potencjalnego wpływu na radykalizację postaw, a tym samym wzrostu popularności organizacji terrorystycznych ${ }^{48}$. Oprócz wskazanych jako zagrożenia powiązane z terroryzmem wymienia zakłócenie dostaw, kryzysy cybernetyczne, ekstremistyczną propagandę i radykalizację postaw, a także nielegalny handel bronią i materiałami wybuchowymi ${ }^{49}$.

\subsection{Czy przewiduje się zaangażowanie aktorów niepaństwowych $\mathrm{w}$ realizację polityki przeciwdziałania terroryzmowi?}

$\mathrm{W}$ unijnej strategii $\mathrm{w}$ dziedzinie walki $\mathrm{z}$ terroryzmem główna odpowiedzialność za zwalczanie terroryzmu spoczywa na państwach członkowskich ${ }^{50}$. Niemniej jednak z racji tego, że to jest strategia unijna, przewiduje się również duże zaangażowanie wspólnoty. Jej rola przede wszystkim ma przybierać cztery główne formy: wzmacniania potencjału krajowego, ułatwiania współpracy europejskiej, budowania zbiorowego potencjału oraz wspierania partnerstwa międzynarodowego ${ }^{51}$. Strategia zakłada więc aktywną rolę UE i jej agencji, a nie tylko udział państw i agencji rządowych ${ }^{52}$. Poza nimi w dokumencie przewidziana jest istotna rola organizacji międzynarodowych i regionalnych, a także ugrupowań obywatelskich i religijnych ${ }^{53}$. Widać więc, iż unijna strategia $\mathrm{w}$ dziedzinie walki z terroryzmem zakłada istotne zaangażowanie aktorów niepaństwowych.

Europejska agenda bezpieczeństwa wskazuje również, że to głównie państwa członkowskie ponoszą odpowiedzialność za prowadzenie polityki zwalczania terroryzmu. Jednak, podobnie jak unijna strategia w dziedzinie zwalczania terroryzmu, zakłada zaangażowanie Unii Europejskiej i jej agencji. Poza tymi aktorami europejska agenda bezpieczeństwa przewiduje również udział w tych działaniach niepaństwowych podmiotów, takich jak przedsiębiorstwa sektora IT

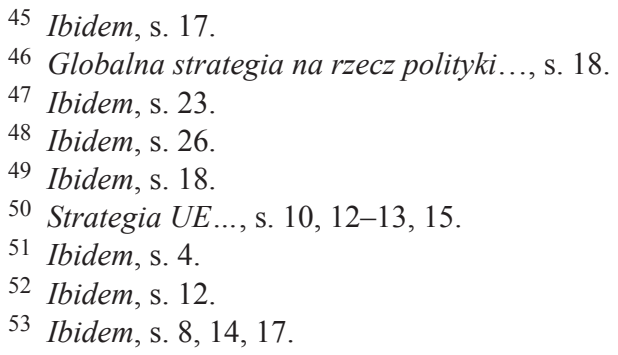


i bankowego, przedstawiciele społeczeństwa obywatelskiego i podmioty lokalne, pracownicy socjalni, pracownicy służby zdrowia, nauczyciele, ale również wybitne osobistości ze świata muzułmańskiego ${ }^{54}$. Tak więc spektrum aktorów zaangażowanych w politykę antyterrorystyczną jest niezwykle szerokie i wpisuje się w paradygmat Human Security ${ }^{55}$.

W globalnej strategii UE nie wskazuje się tak wyraźnie dominującej pozycji państw członkowskich w realizacji polityki zwalczania terroryzmu. Dokument ten skupia się przede wszystkim na roli, jaką mają odegrać w tym wymiarze agencje unijne. Wymienia on przede wszystkim wspólne powiadomienia o brutalnym ekstremizmie, siatkach terrorystów i zagranicznych bojownikach terrorystycznych, a także wspólne monitorowanie i usuwanie nielegalnych treści w mediach ${ }^{56}$. Oprócz tego strategia mówi o konieczności ustanowienia lub rozbudowywania partnerstwa ze społeczeństwem obywatelskim, podmiotami społecznymi, sektorem IT i bankowym oraz ofiarami terroryzmu ${ }^{57}$. Dokument wskazuje również na znaczenie współpracy z organizacjami regionalnymi (m.in. ASEAN, Unia Afrykańska), a także organizacjami międzynarodowymi, w tym — przede wszystkim - $\mathrm{z} \mathrm{ONZ}^{58}$.

\section{Wnioski - czy unijna polityka przeciwdziałania terroryzmowi oparta jest na paradygmacie Human Security?}

Analiza unijnych dokumentów strategicznych bardzo wyraźnie pokazała, że są one oparte na paradygmacie Human Security. Całościowe dokumenty strategiczne, $\mathrm{tj}$. europejska agenda bezpieczeństwa i globalna strategia UE, wskazały terroryzm jako jedno z głównych zagrożeń bezpieczeństwa Unii i jej państw członkowskich. Wszystkie trzy analizowane dokumenty strategiczne podkreślają, że podstawowym podmiotem ochrony w ramach polityki zwalczania terroryzmu jest człowiek, a dokładniej obywatel Unii Europejskiej ${ }^{59}$. Tak więc pierwsze kryterium zostało zweryfikowane pozytywnie.

Podsumowując analizę nad drugim kryterium, należy podkreślić, że unijna strategia $\mathrm{w}$ dziedzinie walki z terroryzmem, europejska agenda bezpieczeństwa

54 Komunikat Komisji do Parlamentu..., s. 15-19.

55 A. Gajda uznaje to za ogromną zaletę agendy. Zob. A. Gajda, Polityka bezpieczeństwa wewnętrznego Unii Europejskiej, „Studia z Polityki Publicznej” 2015, nr 3 (7), s. 55.

56 Globalna strategia na rzecz polityki..., s. 18.

57 Ibidem, s. 21, 27.

58 Ibidem, s. 32, 36, 41.

59 Pytanie, które należy w tym miejscu postawić, dotyczy tego, czy mieszkańcy Unii bez jej obywatelstwa nie są przedmiotem ochrony w ramach polityki bezpieczeństwa, $w$ tym polityki zwalczania terroryzmu. 
oraz globalna strategia UE szeroko definiują zagrożenia związane z terroryzmem. Wskazują jako zagrożenie nie tylko sam akt terroru, ale również to, co do niego prowadzi (m.in. radykalizację postaw, propagandę internetową, szkolenia, współpracę ze zorganizowaną przestępczością) oraz następuje po nim (np. konsekwencje dla ofiary terroru). Zostało więc wykazane, że zagrożenia związane z terroryzmem są traktowane przez te dokumenty szeroko, wykraczając poza tradycyjnie pojmowane bezpieczeństwo. Co jednak istotne, w myśl analizowanych strategii zagrożeniem jest to, co wpływa na poczucie bezpieczeństwa jednostki ludzkiej, ale niekoniecznie jest bezpośrednio związane $\mathrm{z}$ aktem terroru, np. trudności odczuwane przez bliskich ofiar zamachów terrorystycznych, którzy pochodzą z innych państw członkowskich, lub zagrożenia związane z imprezami masowymi. Tak więc $\mathrm{w}$ przypadku omawianych dokumentów mamy również pozytywnie zweryfikowaną przesłankę drugą.

Trzeci warunek uznania, że unijna polityka przeciwdziałania terroryzmowi zdefiniowana $\mathrm{w}$ dokumentach strategicznych oparta została na paradygmacie Human Security, również został spełniony. Wszystkie analizowane dokumenty przewidują zaangażowanie w politykę bezpieczeństwa aktorów niepaństwowych, w tym przede wszystkim Unii Europejskiej i jej agencji. Mocna pozycja wspólnoty w tej polityce jest tak oczywista, ponieważ przeanalizowane strategie zostały przygotowane przez podmioty unijne, tj. Komisję Europejską oraz wysokiego przedstawiciela do spraw zagranicznych i polityki bezpieczeństwa. Trudno byłoby w takiej sytuacji oczekiwać marginalizacji roli odgrywanej przez wspólnotę, ponieważ mijałoby się to z celem przygotowywania takich strategii na poziomie ponadnarodowym. Jednak poza aktorami unijnymi przewiduje się również aktywną rolę podmiotów lokalnych, przedstawicieli społeczeństwa obywatelskiego, nauczycieli, wychowawców, liderów społeczności muzułmańskiej, przedsiębiorstw z sektora IT i bankowego, a także organizacji międzynarodowych. Niemniej jednak, co warto podkreślić, wszystkie te dokumenty zakładają dominującą rolę państw członkowskich i ich służb oraz agencji w tym obszarze, co wskazuje utrzymanie się jednak tej polityki w orbicie kompetencji krajów członkowskich. To zaś nie zmniejszy istniejących problemów we współpracy pomiędzy agencjami poszczególnych państw, a więc i nie podniesie efektywności omawianej polityki ${ }^{60}$.

\section{Zakończenie}

Przeprowadzona analiza wykazała wyraźnie, że w unijnych dokumentach strategicznych polityka przeciwdziałania terroryzmowi konstruowana jest w oparciu o założenia paradygmatu Human Security. Aktywność ta skoncentrowana jest przede wszystkim na zapewnieniu poczucia bezpieczeństwa jednostce ludzkiej

60 S. Wojciechowski, op. cit. 
(obywatelowi UE), definiuje szeroko zagrożenia związane z terroryzmem, a także przewiduje zaangażowanie aktorów niepaństwowych. Tak więc potwierdzone zostały trzy wskazane w niniejszej pracy wyznaczniki podejścia opartego o bezpieczeństwo ludzkie. Tym samym tytułowa polityka wpisana jest w szeroko pojmowaną politykę bezpieczeństwa Unii Europejskiej i to w jej wymiarze zarówno wewnętrznym, jak i zewnętrznym. Takie podejście jest zrozumiałe, jeśli wziąć pod uwagę podmioty zaangażowane $\mathrm{w}$ tworzenie analizowanych dokumentów strategicznych. Trudno bowiem oczekiwać, aby Komisja Europejska czy wysoka przedstawiciel do spraw zagranicznych i polityki bezpieczeństwa tworzyły dokumenty, w których w marginalny sposób definiowana byłaby rola instytucji i agencji unijnych. A to można było osiągnąć jedynie opierając się na paradygmacie Human Security przewidującym duże zaangażowanie aktorów niepaństwowych. Jednocześnie podkreślanie w analizowanych dokumentach strategicznych tego, że przedmiotem ochrony polityki przeciwdziałania terroryzmowi jest obywatel UE, wskazuje na chęć legitymizacji swojej aktywności w tym wymiarze w oczach mieszkańców wspólnoty. Unia w myśl tych dokumentów ma służyć ludziom, a nie państwom. Niemniej jednak realne kompetencje i odpowiedzialność pozostały przy rządach i ich agencjach, co wskazuje na utrzymanie tego obszaru polityki bezpieczeństwa w gestii państw członkowskich. To zaś powoduje, że pomimo oparcia unijnej polityki antyterrorystycznej o paradygmat Human Security realne działania poszczególnych rządów mogą odzwierciedlać tradycyjne podejście do bezpieczeństwa. Niemniej jednak wydaje się, iż wraz ze wzmocnieniem kompetencji instytucji unijnych bezpieczeństwo ludzkie może zacząć przenikać ze wspólnotowych dokumentów strategicznych na unijną legislację w tej dziedzinie, a tym samym do prawodawstwa krajowego. A to będzie oznaczało, że również państwa członkowskie, niechętne temu podejściu, będą musiały z czasem zmodyfikować swoją aktywność w kierunku bliższym Human Security.

\section{Bibliografia}

Bajpai K., The idea of Human Security, „International Studies” 40, 2003, nr 3.

Beyer C., The European Union as a Security Policy Actor: The Case of Counterterrorism, „European Foreign Affairs Review” 13, 2008, nr 3.

Decyzja ramowa Rady z dnia 13 czerwca 2002 r. w sprawie zwalczania terroryzmu (2002/475/ WSiSW), Dz. Urz. UE z 2002 L 164/3.

Den Boer M., 9/11 and the Europeanisation of Anti-Terrorism Policy: A Critical Assessment, „Policy Papers" 2003, nr 6.

Durys P., Jasiński F., Zwalczanie terroryzmu w ramach Unii Europejskiej, „Wspólnoty Europejskie” 2000, nr 6 (106).

Europejczycy w 2016 r.: Wyobrażenia i oczekiwania, walka z terroryzmem i radykalizacja postaw. Wydanie specjalne Eurobarometru Parlamentu Europejskiego, 2016, PE 570423, http://www. europarl.europa.eu/pdf/eurobarometre/2016/attentes/eb85_1_synthesis_perceptions_wishes_ terrorism_pl.pdf. 
Europejska strategia bezpieczeństwa „Bezpieczna Europa w lepszym świecie”, http://www.consilium.europa.eu/uedocs/cmsUpload/031208ESSIIPL.pdf.

Fukuda-Parr S., C. Messineo, Human Security: a critical review of the literature, „CRPD Working Paper" 2012.

Fukuyama F., Koniec historii, thum. T. Bieroń, M. Wichrowski, Kraków 2009.

Gajda A., Polityka bezpieczeństwa wewnętrznego Unii Europejskiej, „Studia z Polityki Publicznej” 2015, nr 3 (7).

Gierszewski J., Unia Europejska w walce z terroryzmem międzynarodowym, „Acta Pomerania” 2009, $\mathrm{nr} 2$.

Globalna strategia na rzecz polityki zagranicznej i bezpieczeństwa Unii Europejskiej „Wspólna wizja, wspólne działanie: Silniejsza Europa", http://eeas.europa.eu/archives/docs/top_stories/ pdf/eugs_pl_.pdf.

Gruszczak A., Governing Internal Security in the European Union, „CEJISS” 3, 2010, nr 2.

Human Development Report 1994, New York-Oxford 1994.

Kaldor M., Human Security: Reflections on Globalization and Intervention, Cambridge 2007.

Komunikat Komisji do Parlamentu Europejskiego, Rady, Europejskiego Komitetu Ekonomiczno-Społecznego i Komitetu Regionów, Europejska agenda bezpieczeństwa, Strasburg, 28.04.2015, $\operatorname{COM}(2015) 185$ final.

Koziej S., Strategia globalna UE: szanse i dalsze wyzwania wdrożeniowe, „Pułaski Policy Papers” 2017.

Paris R., Human Security. Paradigm Shift or Hot Air?, „International Security” 26, 2001, nr 2.

Resztak I., Zwalczanie terroryzmu w świetle dokumentów Unii Europejskiej, „Prokuratura i Prawo” 2013, nr 5.

Rothschild E., What is Security, „Daedalus” 124, 1995, nr 3.

Strategia bezpieczeństwa wewnętrznego Unii Europejskiej „Dązac do europejskiego modelu bezpieczeństwa", 2010, https://europa.eu/globalstrategy/en/file/10/download?token=ubYn8qBQ.

Strategia UE $w$ dziedzinie walki z terroryzmem, Bruksela 30.11.2005, 14469/4/05, http://register. consilium.europa.eu/doc/srv?f=ST+14469+2005+REV+4\&l=pl.

Study Group on Europe's Security Capabilities, A human security doctrine for Europe: the Barcelona report, 2004, http://www.lse.ac.uk/internationalDevelopment/research/CSHS/humanSecurity/barcelonaReport.pdf.

Sus M., Member States as Strategy-Maker or Strategy-Taker?, „Polish Political Science Yearbook” 2016, nr 45.

Szacher D., Walka z terroryzmem w Unii Europejskiej — nowy impuls, Torun 2006.

Tarnogórski R., Human Security: Reactivation of an Idea?, „PISM Strategic File” 2013, nr 2.

Tereszkiewicz F., Europejska strategia bezpieczeństwa wobec wspótczesnych wyzwań bezpieczeństwa Unii Europejskiej, [w:] Współczesna polityka bezpieczeństwa. Aspekty polityczne, gospodarcze i militarne, red. P. Grata, M. Deląg, P. Korzeniowski, Rzeszów 2016.

Trachsler D., Human Security: Genesis, Debates, Trends, „CSS Analysis in Security Policy” 2011, nr 90.

ul Haq M., Reflections on Human Development, New York 1995.

Wojciechowski S., Polityka antyterrorystyczna Unii Europejskiej — syndrom , różnych prędkości” i próby jego ograniczenia, „Biuletyn Instytutu Zachodniego” 2017, nr 298.

Zwitter A., Human Security, Law and the Prevention of Terrorism, London-New York 2011.

Studia nad Autorytaryzmem i Totalitaryzmem 40, nr 1, 2018

(C) for this edition by CNS 


\section{AN ANALYSIS OF EU STRATEGIC DOCUMENTS: MAKING HUMAN SECURITY A PARADIGM WITHIN EUROPEAN UNION COUNTERTERRORISM POLICY}

\section{Summary}

This paper analyses European Union strategic documents for evidence that EU counterterrorism policy is founded on the Human Security (HS) approach. It concentrates on three main strategic documents: the EU Counter-Terrorism Strategy (2005), the European Agenda on Security (2015), and the EU Global Strategy (2016) which define the EU's current approach to terrorism. Three determinants are established to research whether counterterrorism policy is founded on the HS paradigm: a people-centred approach, the presence of a wide range of threats, and a strong presence of non-state actors. The analysis shows that counterterrorism policy is constructed on the HS paradigm, however with strong and influential leverage from member states. This paradigm was chosen by EU institutions because it guarantees a strong position of EU agencies in contrast to the traditional member state-centred approach to security. It helps also to show that EU security policy makes citizens a priority, which could increase legitimacy of the EU in the eyes of its people.

Keywords: EU security policy, terrorism, Human Security

Filip Tereszkiewicz

f.tereszkiewicz@gmail.com 